\title{
Discussion on Financial Management and Internal Control of Enterprise Accounting
}

\author{
Yuting Huang*, Jiana Liu \\ Nanchang Institute of Science and Technology, Nanchang, Jiangxi, China
}

Keywords: Accounting financial management; internal control; discussion

\begin{abstract}
The development of market economy has put forward higher requirements for modern enterprise management. Financial management is an important part of enterprise management. The internal control of financial management is directly related to the economic safety of enterprises. Through the internal control of financial management, enterprises can understand the accurate financial information and improve the utilization ratio of enterprise assets. This paper specifically discusses the financial management and internal control of enterprise accounting, hoping to provide some references for the relevant people.
\end{abstract}

Since reform and opening-up, China's trade with the rest of the world are more and more close, the deepened reform measures and the rapid development of the socialist market economy, the development of various industry provides a good condition in our country, bringing huge enterprise development space, both opportunities and challenges. With the growing number of enterprises of all types of enterprises involved in the business area is becoming more and more extensive and complex, the influence of all kinds of risks to the enterprise operation is also increasing, characterized by internal accounting control, which has risen to the enterprise strategic decision. Financial accounting from behind the scenes to the front desk, plays an important role in the enterprise management, therefore, enterprises should optimize financial management and internal accounting control, seize the development opportunities, improve their management level.

\section{Overview of Corporate Accounting Financial Management and Internal Control}

The so-called enterprise accounting and internal control, financial management is the enterprise internal financial personnel, supervision, personnel with scientific theory of internal control, to enterprise's production and operation situation to supervise and regulate, to ensure the normal operation of enterprises, and to avoid a major financial problem ${ }^{[1]}$.

\section{Importance of Accounting and Financial Management and Internal Control}

\subsection{To ensure the security of enterprise funds}

First of all, accounting financial management and internal control can guarantee the financial security of enterprises. In the process of production and management of enterprises, enterprises take economic benefits as the ultimate goal. Capital risk mainly reflected in the liquidity risk, the internal control through the budget control, examining and approving control, separation of incompatible duties and other measures to help enterprises to do a good job of protection funds, inventory of the enterprise funds, accounting of capital expenditures and verification of enterprise purchasing situation, and so on. Through internal control, the financial security of enterprises can be effectively guaranteed.

\subsection{To provide accurate accounting information}

Secondly, accounting financial management and internal control can provide accurate accounting information for enterprises. Internal control requires the authenticity and reliability of accounting information. In current enterprises, accounting information distortion often occurs, which affects the 
healthy development of enterprises. Accounting information distortion is caused by many factors, including human factors, material factors, internal control can be staff strictly distinguish between authority and responsibility, and carries on the repeated verification of accounting information, effective supervision on financial management process, once the intermediate links appear problem, internal control will immediately solve the problem, so as to provide accurate accounting information for the enterprise.

\subsection{To improve the utilization efficiency of funds}

Thirdly, accounting financial management and internal control can improve the efficiency of enterprise capital utilization. The reason why enterprises set up financial management departments internally is to manage their own costs and obtain the maximum economic benefits with limited expenditures. The internal control of enterprise financial management can improve the utilization rate and investment efficiency of enterprise capital. Internal control, for example, can be calculated to the enterprise internal inventory, making the corresponding plan according to the market situation, combined with changes of supply and demand adjustment procurement policy, through the internal control, the application of enterprise funds can optimize and create more economic value for the enterprise.

\section{Current Problems in China's Corporate Accounting and Financial Management and Internal Control}

\subsection{Weak awareness of accounting financial management and internal control}

First of all, in some Chinese enterprises, the awareness of internal control is weak.In the current market economy environment, the competition among enterprises is increasingly fierce, and the internal accounting and financial management of enterprises is directly related to the competitiveness of enterprises. Many enterprises did not realize the importance of accounting of financial management, enterprise internal not to carry out the relevant financial management rules, no strict internal control measures, make the enterprise management is very difficult to reach the expected effect, hindered the sustainable development of enterprises.

\subsection{The low personnel quality of enterprise accounting financial management and internal control}

Secondly, in some enterprises of our country, the quality of internal control personnel is relatively low. Accounting and financial management involves all aspects of an enterprise, including a wide range of contents. Therefore, internal control personnel should not only master professional accounting skills, but also have good comprehensive elements Quality. In the actual process of financial management, the quality of managers needs to be improved, the knowledge system has lagged behind the trend of The Times, and the business knowledge has not kept pace with The Times. The failure of financial personnel to make reasonable adjustments to the accounting measurement of enterprises in accordance with the latest accounting standards and systems has directly affected the quality of financial management.

\subsection{The imperfect system of accounting financial management and internal control}

Third, in some enterprises in China, the internal control system is not sound enough. System is the key to standardize behavior, but many enterprises fail to realize the importance of internal control system, which makes the internal financial management of enterprises into a chaotic state.In the absence of rules and regulations, the staff in the enterprise are not highly motivated to work, muddling along in the work and not thinking about making progress, which affects the sustainable development of the enterprise.

\subsection{The weak supervision of accounting financial management and internal control}

Finally, in some Chinese enterprises, the internal control of the supervision of weak. Although most enterprises in China have adopted corresponding internal control methods, there is still a 
problem of insufficient supervision. Enterprises in the process of internal control, without effective supervision, will make internal control effective as it should be lost, led to a spate of accounting information distortion problem ${ }^{[2]}$.At the same time, staff lost supervision, there will also be a problem of negative work neglect.

\section{Optimize the Accounting Financial Management and Internal Control of Chinese Enterprises}

\subsection{To improve the awareness of accounting financial management and internal control}

First of all, Chinese enterprises should strengthen the awareness of internal control. The business strategy of an enterprise will be affected by the internal control of accounting and financial management. Therefore, only through internal control can a scientific development strategy be formulated to improve the economic benefits of the enterprise. Enterprises should formulate corresponding internal control systems, provide accurate accounting information, and make development plans according to accounting information. At the same time, enterprises should follow the laws and regulations of the state and standardize the work behaviors of their financial managers, so as to improve their financial management level and promote the improvement of their comprehensive competitiveness.

\subsection{To improve the personnel quality of enterprise accounting financial management and internal control}

Secondly, Chinese enterprises should improve the quality of internal control staff. When selecting financial management personnel, enterprises should follow certain selection criteria and check the professional knowledge and moral cultivation of staff members. In addition, enterprises should provide regular training to existing internal control personnel, so that the staff can learn advanced management experience and management methods. In order to improve the quality of internal control staff, enterprises should also provide opportunities for external communication and education, so as to timely grasp the new financial dynamic knowledge and improve their professional level. After the internal control staff have worked for a certain period of time, the enterprise should evaluate their work and establish corresponding incentive and punishment mechanism. In the process of job assignment, the mechanism of regular job rotation should be formed to give full play to the function of internal control and improve the work responsibility and moral level of the staff under internal control.

\subsection{To improve the accounting and financial management and internal control of enterprises}

Thirdly, Chinese enterprises should improve the accounting financial management and internal control system. Accounting financial management and internal control system is the fundamental guarantee for enterprise financial management, so enterprises must improve the system, based on the enterprise financial information system, to integrate the various information and analysis, to guide the production and business operation activities of the enterprise. At the same time, enterprises can apply the computer technology, the financial information for effective verification, through to the accounting and financial information, and can improve the quality of financial management, enhance the management level of internal control.

\subsection{To supervise the accounting financial management and internal control of enterprises}

Finally, Chinese enterprises should strengthen the supervision of accounting financial management and internal control. The enterprise internal supervision system involves in all aspects of enterprise production and operation activities, the supervision system in the supervision of the daily activities, it should also be to enterprise's financial management and internal control work. Control key points, ensure the authenticity and reliability of accounting information, and help enterprises formulate correct development plans. To strengthen control, enterprises should follow the principle of clear rights and responsibilities, clarify the responsibilities of staff and supervisors, 
and form a balanced development mechanism within enterprises. Business must be separated from supervision and audit, so as to restrict each other's work behavior and ensure the smooth progress of supervision.

\section{Conclusion}

The continuous development of China's socialist market economy has put forward higher requirements for the production and operation of enterprises. Management level is directly related to the development of enterprises. Therefore, enterprises should improve their management quality and maintain a favorable position in the fierce market competition. Financial management is an important link in enterprise management, perfect the internal control can provide enterprises with accurate accounting information, help enterprises to make scientific development planning, reduce the risk and maximize function of money, in order to optimize the internal control, enterprise should strengthen the consciousness of internal control, to improve the quality of the staff, perfecting the internal control system, the internal control to carry on the effective supervision, so as to improve the level of accounting of financial management, promote the sustainable healthy development of the enterprise.

\section{References}

[1] Liu Bin. Characteristics of audit committee, internal control defects of financial reports and quality of accounting information [D]. Tianjin university of finance and economics, 2014.

[2] Liu. How to strengthen the internal control work in the new period[J]? Modern shopping mall, 2015 (3)

[3] Luo Hongjun. Analysis on the strengthening strategy of internal control in the accounting and financial management of enterprises in the new era [J]. Accounting of Chinese township enterprises, 2015 (7)

[4] Li Qi. How to strengthen internal control in enterprise accounting and financial management [J]. Operation manager, 2016 (5) 